\title{
Inheritance of Resistance to Midge, Contarinia sorghicola Coq. in Sorghum, Sorghum bicolor (L.) Moench*
}

\author{
B. L. Agrawal, C. V. Abraham and L. R. House $\dagger$ \\ Cereals Improvement Program, International Crops Research Institute for the Semi-Arid Tropics
}

(ICRISAT), Patancheru P.O., Andhra Pradesh 502 324, India.

(Received 16 December 1986; revised 9 April 1987)

\begin{abstract}
Inheritance of resistance to sorghum midge, Contarinia sorghicola Coq. was studied on a set of 21 diallei crosses involving four midge-resistant and three susceptible sorghum, Sorghum bicolor (L.) Moench cultivars under natural midge infestation at Dharwad during the late rainy season (August to November) 1983. Both additive and nonadditive genetic variances were important for midge resistance. The parents, DJ 6514 and TAM 2566, proved as better general combiners. Mean performance of the parents and their general combining ability (GCA) effects were strongly correlated. Crosses with positive specific combining ability (SCA) effects in both $\mathrm{F}_{1}$ and $\mathrm{F}_{2}$ generations had at least one parent with high GCA effects and better per se midge resistance. Midge-resistant parents, DJ 6514 and TAM 2566, with high per se resistance and GCA effects should be utilized in breeding for midge resistance.
\end{abstract}

Key Words: Sorghum bicolor (L.) Moench, combining ability, midge, Contarinia sorghicola Coq., resistance, infester row, gene action, genetics

\begin{abstract}
Résumé-Cet article présente l'étude de l'héritabilité de la résistance à la cécidomyie du sorgho, Contarinia sorghicola Coq. portant sur un ensemble de 21 croiserients dialièles comprenant 4 cultivars de sorgho, Sorghum bicolor (L.) Moench résistants et 3 sensibles à la cécidomyie. L'étude a été effectuée dans les conditions de l'infestation naturelle par cet insecte à Dharwad, vers la fin de la saison des pluies (août à novembre), 1983. Les variances génétiques additives et les variances génétiques non additives sont toutes les deux importantes pour la résistance à la cécidomyie. Les parents DJ 6514 et TAM 2566 se sont avérés de très bons combinateurs généraux. Une forte corrélation a été constatée entre la performance moyenne des parents et leurs effets d'aptitude générale à la combinaison (AGC). Les croisements avec des effets đ'aptitude spécifique à la combinaison (ASC) positifs au niveau des générations $F 1$ et $F 2$ avaient au moins un parent ayant d'importants effets d'aptitude générale à la combinaison (AGC) et une meilleure résistance à la cécidomyie. Des parents résistants à la cécidomyie, réunissant une forte résistance et des effets AGC importants, doivent être exploités dans la sélection pour la résistance à la cécidomyie.
\end{abstract}

\section{INTRODUCTION}

Considerable genetic variability for plant resistance to sorghum midge, Contarinia sorghicola Coq. is observed among cultivated lines of sorghum, Sorghum bicolor L. (Bowden and Neve, 1953; Wiseman et al., 1974; Raodeo and Karanjkar, 1975; Syamasunder et al., 1975; Venugopal et al., 1977; Wuensche et al., 1978; Faris et al., 1979; Sharma and Davies, 1981). However, success is limited in transferring genetic resistance into commercial cultivars, partially due to inadequate information on the genetic nature of this trait. Recently, Patil and Thombre (1982), and Henzel et al. (1986) reported that it is a quantitatively inherited trait governed by additive and nonadditive gene effects. Boozaya-Angoon et al. (1984) and Widstrom et al. (1984) reported that complex trait is governed by recessive genes.

The present studies determined the nature of sorghum midge resistance in a seven parent diallel set

*ICRISAT Journal Article No. 615.

$\dagger$ Present address: Executive Director, SADCC/ICRISAT, Sorghum and Pearl Millet Improvement Project, P.O. Box 776, Bulawayo, Zimbabwe. of crosses (excluding reciprocals) both in $F_{1}$ and $F_{2}$ generations.

\section{MATERIALS AND METHODS}

The midge resistance evaluation was conducted on a set of experimental material, consisting of four midge-resistant (TAM 2566, S GIRL-MR 1, AF 28, and DJ 6514) and three midge-susceptible (SPV 422, SPV 351, and SC 108-3) cultivars, and their $21 F_{1}$ 's and $21 \mathrm{~F}_{2}$ 's. The parental cultivars were chosen randomly. All test entries were evaluated for midge resistance in a randomized complete block design with three replications at the University of Agricultural Sciences Farm, Dharwad, Karnataka, India during the 1983 rainy season (July to November) under a delayed planting condition ( 6 weeks later than normal plantings), to enable a satisfactory natural population built up of sorghum midge. The experiment was planted twice (10-day interval) (25 July and 4 August) to expose at least one of the plantings to midge under natural conditions. The midge population was built up by planting infester rows with a bulk of mixed maturity type of sus- 
Table 1. Analysis of variance for combining ability for midge resistance (per cent seed set) in sorghum

\begin{tabular}{lccc}
\hline & & \multicolumn{2}{c}{ Mean squares } \\
\cline { 3 - 4 } Source & $d f$ & $\mathbf{F}_{1}$ & $F_{2}$ \\
\hline $\begin{array}{l}\text { General combining } \\
\text { ability (GCA) }\end{array}$ & 6 & $345.89^{* *}$ & $296.77^{* *}$ \\
$\begin{array}{l}\text { Specific combining } \\
\text { ability (SCA) }\end{array}$ & 21 & $70.56^{* *}$ & $34.03^{* *}$ \\
Error & & & \\
Components: $\sigma^{2} \mathrm{~g}$ & 54 & 14.95 & 3.50 \\
$\quad \sigma^{2} \mathrm{~s}$ & & 30.59 & 29.19 \\
Predictability ratio & & 55.61 & 30.53 \\
$\left(2 \sigma^{2} g / 2 \sigma^{2} g+\sigma^{2} s\right)$ & & 0.524 & 0.657 \\
\hline
\end{tabular}

**Significant at $P=0.01$.

Table 2. Mean performance and general combining ability (GCA) effects of the parents over $F_{1}$ and $F_{2}$ generations for midge resistance in sorghum

\begin{tabular}{lccc}
\hline & & \multicolumn{2}{c}{ GCA effects } \\
\cline { 4 - 4 } Parent & Meen & $\mathrm{F}_{1}$ & $F_{2}$ \\
\hline SPV 422 & 15.7 & $-8.9^{* *}$ & $-8.9^{* *}$ \\
TAM 2566 & 74.1. & $4.7^{* *}$ & $2.9^{* *}$ \\
S-GIRL-MR 1 & 61.6 & $2.3^{* *}$ & $1.5^{* *}$ \\
SPV 351 & 26.6 & $-3.6^{* *}$ & $-2.8^{* *}$ \\
AF 28 & 75.8 & 0.6 & $2.4^{* * *}$ \\
SC 108-3 & 38.9 & $-4.5^{* *}$ & $-4.1^{* *}$ \\
DJ 6514 & 83.5 & $9.4^{* *}$ & $8.8^{* *}$ \\
$r$ & & $0.927^{* *}$ & $0.945^{* *}$ \\
SE $(\hat{g} i)$ & & \pm 1.2 & \pm 0.6 \\
SE $(\hat{g} i-\hat{g} j)$ & & \pm 1.8 & \pm 0.9 \\
\hline
\end{tabular}

Significant at $* P=0.05$ and $* * P=0.0 \mathrm{I}$ :

$r=$ Rank correlation of mean performance and GCA effects.

ceptible cultivars in 4 rows after every 24 rows of test material one month before planting of the test material (Sharma, 1984). The parents and the $F_{1}$ 's were planted in single-row plots; and the $F_{2}$ 's in four row plots of $4 \mathrm{~m}$ length. The interrow spacings were $45 \mathrm{~cm}$ and the intrarow spacings were $15 \mathrm{~cm}$.
Sorghum midge infestations were higher in the second planting (observed 10 to 12 midges per panicle during flowering) and hence the data on midge damage were tecorded in this experimental set only. Midge damage was recorded on individual panicle in terms of percentage seed set by counting the seeds in a random bulk sample of 250 florets drawn from the most-affected portion of the individual panicle. The midge incidence was recorded on five panicles of each parent, and $F_{1}$; and 50 panicles of each $F_{2}$ in each replication. The data on percentage seed set was subjected to arc sine transformation and analysed using method 2, model 2 of Griffing (1956).

\section{RESULTS}

Significant differences were observed among parents, their $F_{1}$ 's, and $F_{2}$ 's for midge resistance (percentage seed set). The mean squares for general combining ability (GCA) and specific combining ability (SCA) were highly significant in $F_{1}$ and $F_{2}$ generations (Table 1). Estimated variance due to GCA was less than that of SCA in the $F_{i}$ generation and almost equal in $F_{2}$ generation. Estimated variance due to GCA exhibited no change from the $F_{1}$ to $F_{2}$ generation, while there was a substantial decrease in variance due to SCA from the $F_{1}$ to $F_{2}$ generation. The predictability tatio was moderate over generations.

Results on GCA effects indicated that all the resistant parents had good combining ability over generations (Table 2). There was good correspondence between mean performance of parents and their GCA effects, except for AF 28. Among resistant parents, DJ 6514 and TAM 2566 were better general combiners and maintained their combining ability of resistance.

Table 3. Mean performance and specific combining ability (SCA) effects of the crosses over $F_{1}$ and $F_{2}$ generations for midge resistance in sorghum

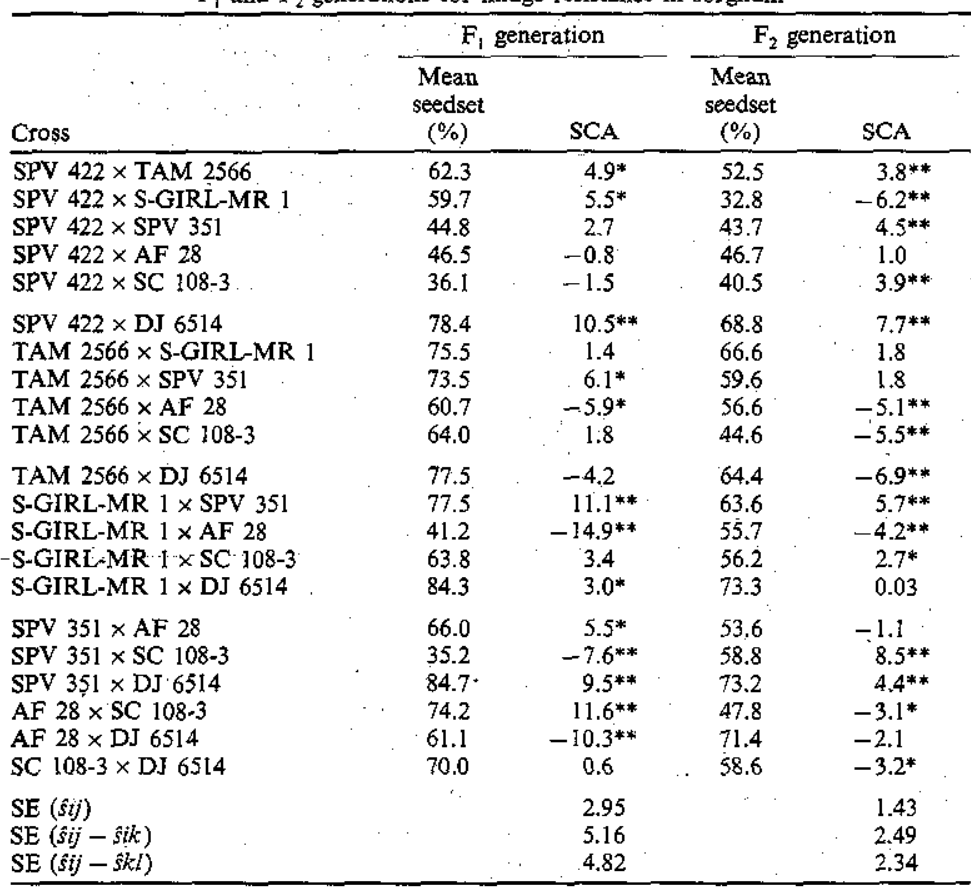

Significant at $* P=0.05$ and $* * P=0.01$. 
The SCA effects showed that SPV $422 \times$ TAM 2566, S GIRL-MR $1 \times$ SPV 351, SPV $422 \times$ DJ 6514, and SPV $351 \times$ DJ 6514 crosses had better SCA effects over generations. Consequently, these crosses had at least one resistant parent with high GCA effects. Crosses involving DJ 6514 , in general, showed better resistance than the crosses with other resistant lines.

\section{DISCUSSION}

There existed sufficient genetic variability for midge resistance in the experimental material studied. The highly significant mean squares observed for GCA and SCA effects over generations, suggested that this trait is under the control of both additive and nonadditive gene effects. Similar observations were made earlier by Patil and Thombre (1982) and recently by Henzel et al. (1986). The decrease noticed in SCA variance from $F_{1}$ to $F_{2}$ generations was as per the nonadditive genetic expectations. The moderate predictability ratio over generations revealed that the better combining midge resistant parents can be partially judged based on GCA effects.

Good correspondence between resistance of parents and their GCA effects clearly indicated that per se resistance is indicative of good combiner for midge resistance. Parents, DJ 6514 and TAM 2566, maintained their GCA for midge resistance over generations, probably due to the presence of more additive genes. The crosses which had more SCA effects over generations, had at least one parent with better midge resistance and high GCA effects, indicated that both per se resistance and the GCA effects are important to realize better heterosis. This is further supported by the fact that the parent $\mathrm{DJ} 6514$ with better midge resistance and high GCA effects contributed good level of resistance in its crosses. Hence, it is concluded that source(s) with better performance and high GCA effects, such as DJ 6514 and TAM 2566, should be utilized as potential midge resistant combiners in breeding for midge resistance.

\section{REFERENCES}

Boozaya-Angoon D., Starks K. J., Weibel D. E. and Teetes G. L. (1984) Inheritance of resistance in sorghum,
Sorghum bicolor, to the sorghum midge, Contarinia sorghicola Coq. (Diptera: Cecidomyiidae), Environ. Ent. 13, 1531-1534.

Bowden J. and Neve R. A. (1953) Sorghum midge and resistant varieties in the Gold Coast, Nature Lond. 172, 551.

Faris M. A., Lira M. de A. and Viega A. F. de. S. L. (1979) Stability of midge resistance. Crop Sci. 19, 577-580.

Griffing B. (1956) Concept of general and specific combining ability in relation to diallel crossing system. Aust. J. Biol. Sci. 9, 463-493.

Henzell R. G., Brengman R. L. and Page F. D. (1986) Breeding for midge resistance in grain sorghum in Queensland. In Proc. First Australian Sorghum Conference, 4-6 Feb 1986. Queensland Agricultural College, Gatton, Queensland, Australia.

Patil R. C. and Thombre M. V. (1982) Inheritance of earhead midge incidence in sorghum. Sorghum Newsl. 25, 90.

Raodeo A. K. and Karanjkar R. R. (1975) Screening of sorghum lines for relative damage by the sorghum midge Contarinia sorghicola (Coq.). Sorghum Newsl. 18, 48-49.

Sharma H. C. (1984) Screening for sorghum midge resistance and resistance mechanism. In Proceedings of International Sorghum Entomology Workshop, 15-21 July 1984. Texas A\&M University, College Station, Texas, USA.

Sharma H. C. and Davies J. C. (1981) A literature review on the sources and mechanisms of resistance to the sorghum midge (Contarinia sorghicola). Sorghum Entomology Progress Report-5. Patancheru, A.P. 502 324, India: International Crops Research Institute for the Semi-Arid Tropics. pp. 22 (limited distribution).

Syamasunder J., Parameswarappa R., Nagaraja H. K. and Kajjari N. B. (1975) DJ 6514 (Pasyana) A new genotype in sorghum resistant to midge [Contarinia sorghicola (Coq.)]. Sorghum Newsl. 18, 33.

Venugopal M. S., Mani M. S., Palanisamy S. and Meenakshi K. (1977) Relative resistance of some promising sorghum lines to sorghum midge, Contarinia sorghicola Coq. Sorghum Newsl. 20, 68.

Widstrom N. W., Wiseman B. R. and McMillan W. W. (1984) Patterns of resistance in' sorghum to sorghum midge. Crop Sci. 24, 791-793.

Wiseman B. R., McMillan W. W. and Widstrom N. W. (1974) International Sorghum Midge Evaluations. Sorghum Newsl. 17, 80.

Wuensche A. L., Teetes G. L., Johnson J. W., Phillips J. M. and Luza T. W. (1978) Studies of sorghum midgeresistant sorghums in progress at Texas A\&M University. Sorghum Newsl. 21, 107-108. 